\title{
HISTORY OF DEVELOPMENT ON MUSLIM WOMEN'S EDUCATION EMPOWERMENT THROUGH WASATIYYAH CONCEPT IN BRUNEI DARUSSALAM
}

\author{
Lilly Suzana Shamsu \\ Universiti Islam Sultan Sharif Ali, Negara Brunei Darussalam \\ Bandar Seri Begawan, Brunei-Muara, Brunei Darussalam \\ Email: lilly.shamsu@unissa.edu.bn
}

Received: 06, 2018. Accepted: 01, 2019. Published: 01, 2019.

\begin{abstract}
This article is an attempt to explore the application of Wasatiyyah in the education system in Brunei Darussalam. This research will be focusing on the advancement of Muslim women's education since the Nation's Policy of Education has been formulated. In such, Annual Education Report and related government official documents are to be analyzed as the main resource in this article. In brief, the methodology used is library research which will be presented in descriptive and narrative approach. As a result, the research found that it is certainly notable $W$ asatiyyah concept is part of the country education system. It is clear and noticeable with no restriction on gender to enroll in all schools. The opportunity to get an education is equally open to all children. Besides, the government is constantly offering and encouraging all adult Muslim women to engage in long life learning with providing them with adult education to enhance their skills and knowledge in numerous field.
\end{abstract}

Keywords: Education, Muslim Women, Negara Brunei Darussalam, Wasatiyyah

\begin{abstract}
ABSTRAK
Artikel ini mencoba untuk mengeksplorasi penerapan Wasatiyyah dalam sistem pendidikan di Brunei Darussalam. Penelitian ini berfokus pada kemajuan pendidikan wanita Muslim karena Kebijakan Pendidikan Bangsa telah dirumuskan. Laporan Pendidikan Tabunan dan dokumen resmi pemerintab terkait akan dianalisis sebagai sumber utama dalam artikel ini. Secara singkat, metodologi yang digunakan adalah penelitian kepustakaan yang akan disajikan dalam pendekatan deskriptif dan naratif. Alhasil, penelitian ini menemukan babwa konsep Wasatiyyah tentu saja merupakan bagian dari sistem pendidikan negara di Brunei Darussalam. Jelas dan nyata tanpa batasan gender untuk mendaftar di semua sekolah. Kesempatan untuk mendapatkan pendidikan sama-sama terbuka untuk semua anak. Selain itu, pemerintab terus-menerus menawarkan dan mendorong semua wanita Muslim dewasa untuk terlibat dalam pembelajaran seumur bidup dengan memberikan mereka pendidikan untuk meningkatkan keterampilan dan pengetabuan mereka di berbagai bidang.
\end{abstract}

Kata Kunci: Pendidikan, Muslimah, Negara Brunei Darussalam, Wasatiyyah

\section{INTRODUCTION}

The term "Wasatiyyah" which is originally mentioned in verse 143 from Surah al-Baqarah is uttered as "wasata". Then the Prophet (peace be upon him) pointed out that "wasata" in the above verse means "adil" (fair) as narrated by Tirmizi from Abu Sa id al-Khudri. Imam Tirmizi stated that this hadis is hasan sabih (al-Tirmizi, 1998) and thus the majority of Muslim scholars in the field of tafsir define the term "wasata" as "adil" (fair) (al-Tabari, 2000). Al-Razi in his tafsir claimed that the meaning of "wasat" is closer to "fair" because it is about being fair without any intention to incline to one party amongst other parties that were having conflict (Al-Tabari, 2000). Furthermore, al-Razi was also in favor to adopt "preferred" (al-Khiyar) in defining "wasat" (Razi, 1420H). His consideration in choosing "preferred" to denote "wasat" was due to the verse 110 in surah Aali 'Imran. 
Al-Razi asserted that the preferred term is the "best" (khayr). Similarly, to what al-Qurtubi has explained that for those who are being in the middle of the tribe are the best and noble. He also stated that the best wadi was the one situated in the middle (al-Qurtubi, 1964). In brief, all interpretation given by Muslim scholars can be concluded as "fair" and "the best" or "excellent" to define "wasata".

In relation to this, an event called the Knowledge Convention 2015 which is one of the biggest national conferences in the country has selected this theme to be discussed, which was "Wasatiyyab is the Core to the Universe Wellbeing".

The State Mufti presented his paper during the opening ceremony of Knowledge Convention emphasized that "wasata" which was stated in verse 143, Surah al-Baqarah does not mean just moderate or middle of something. According to the State Mufti the meaning of "wasata" is exactly what has been interpreted by the mufassirun in their tafsir were: the best; the highest; the greatest; the fairest and the most important. He argued that it is inappropriate to associate moderation into Islam. He highlighted this statement in his keynote presentation:

"... So it is very disappointing to suddenly hear that some people are rendering the word a different interpretation: an interpretation that is different from that given by the language experts and experts in the Science of Quranic Exegesis. They have interpreted "wasata" and "khayr" as "moderate". Meaning to say the Muslim ummah is an ummah that is moderate and Islam too is a moderate religion. What is most disappointing is when this "moderation" is explained as not extreme, as compromising, giving in, very prepared to entertain all wishes or desires, although these may go against the 'aqidah (faith) or undermine dignity, all in the name of Islam, the moderate religion, and Muslims the moderate ummah. We see this interpretation as alien to Islam. Islamic W asatiyyah does not mean a moderate Islam. Islamic Wasatiyyah is the highest Islam, the greatest Islam" (Juned, 2015).

The Rabbani's term "Wasatiyyah" has increasingly being debated in this decade particularly when some people started to accuse Islam of doing 'injustice' and involving in extremism and terrorism. Terrorist attacks that happened during this had been associated with Muslim and linked directly to Islam. The religion of Islam has been perceived by people as a violent, radical and inhumane system of belief. The media especially western media often misrepresented the reality and the truthfulness of Islam and causing false allegations towards. This scenario undoubtedly has turned into a huge burden to all Muslims. On the other hand, all Muslims need to voice out the truth about Islam in responding for the global allegation towards Islam. It is a duty to every Muslim to correct and convey the pure message of Islam. Islam is a way of life that promotes peace and harmony and not the contrary.

In this regard, despite Brunei Darussalam is physically small it tries to respond to this issue of misinterpreting Islam by organizing a national seminar to highlight the "Wasatiyyab" concept. Even though the term "Wasatiyyah" has widely discussed by scholars and researchers but, there are still rooms for discussions due to its broad perspectives. Thus, His Majesty Paduka Seri Baginda Sultan and Yang Di-Pertuan Brunei Darussalam mentioned in his decree during the officiating of the opening ceremony of the Knowledge Convention in 2015:

"...about W asathiyyah, we have heard a lot about it but in my opinion it is always relevant to discuss since knowledge has no border and it is wide and broad. Thus, we may dig and continue to dig deeper into Wasathiyyah. What actually is Wasathiyyah? What are its content and the philosophy behind it? All these issues are matter and beneficial to all".

In line with the issue addressed above, there is a lack of studies investigating the issue. Education for Muslim women in Brunei Darussalam has not been investigated by researchers. Therefore, this study tries to fill the gap. To be specific this study seeks to explore the initiative to embark research on "Wasatiyyah" with focusing on the application of "Wasatiyyah" concept in Brunei Darussalam especially for Muslim women in their education chance and opportunity in the country. 


\section{METHOD}

This study used a descriptive case study method that explain a history of development on Muslim women's education. Moreover, "descriptive studies may be characterized as simply the attempt to determine, describe or identify what is, while analytical research attempts to establish why it is that way or how it came to be" (Edcridge, 1995; Khotari, 2004). Descriptive research is "aimed at casting light on current issues or problems through a process of data collection that enables them to describe the situation more completely than was possible without employing this method (Fox \& Bayat, 2008; Miles \& Huberman, 1994). In its essence, descriptive studies are used to describe various aspects of the phenomenon. In its popular format, descriptive research is used to describe characteristics and/or behavior of the sample population. In brief, the methodology used in this study is library research which will be presented in descriptive and narrative approach.

\section{RESULTS AND DISCUSSION \\ Wasatiyyah Concept in Brunei Education}

It is inevitable that excellent and fairest are the characteristic in Wasatiyyah and not the moderation. However, balance is considered as one of Wasatiyyah's concepts because it embraced values of just or fair and avoiding from being biased. However, moderate means always be equally divided regardless of the situations. In the early Islamic history, it was recorded that companions such as Abu Bakar radiallabu 'anbu donated all of his wealth to support Islam. He did not spare any of his wealth for his family but his decision was accepted as Wasatiyyah. This is an example of a noble deed for doing appropriate action in a very significant situation.

The Prophet (peace be upon him) did the similar deed. He has advised and disapproved a few of his companions' actions who promised to continuously fasting, praying at night (qiyam al-lay) and refused to get married in order to consistently devote to Islamic teachings. This is because they failed to demonstrate moderation and also to clarify that in living they need to balance their life well. This is because living people requires communication and interaction with others and being kind to them or other creatures in the universe are regarded as a religious act (ibadah).

In another occasion, such as during the last ten days of the month of Ramadhan the Prophet (peace be upon him) will actively increasing his religious activities and encourage his family to perform the night prayer (qiyam al-lay) together. Although it seemed to contradict with his previous judgment, it actually has the same objective which is to do the best and greatest action in a specific time. The Prophet has set the best example in his life to be observed by his followers to lead their life simultaneously by explaining the meaning of $W$ asatiyyah. Obviously, the most excellent, the fairest or well-balanced ummah are the right values to deal with extremist threats. It is the absolute approach to overcome current conflict in terrorism. Thus, His Majesty suggested to promote and educate the concept of $W$ asatiyyab to tackle and combat these global challenges during US-ASEAN Leaders Summit Retreat 22016 (Pelita Brunei, 2016).

In this paper, the concept of $W$ asatiyyah will be analyzed through the characteristics of fair and the best or excellent in the aspect of education that will be focusing on Muslim women's education in Brunei Darussalam. In general, women education is essential for women because they will be nurturing their children and acting as the first 'school' for all their toddlers. Education for them is not necessary to obtain an official job as an educator. It will equip and occupy themselves with proper parenting skills that met the needs to take care of and educate their children.

In Brunei Darussalam, Muslim women population is almost as many as Muslim men population (shown in Table 1). Hence, their role is very much important as men's role in 
developing the country. If women are left behind then, the nation will suffer a slow economy and social growth.

Table 1. Muslim Women Population

\begin{tabular}{cccc}
\hline Year & Muslim Population & $\begin{array}{c}\text { Muslim Women } \\
\text { population }\end{array}$ & $\begin{array}{c}\text { Muslim Women's } \\
\text { Percentage }\end{array}$ \\
\hline 1981 & 122,912 & 59,912 & $49 \%$ \\
\hline 1991 & 174,973 & 87,066 & $49.7 \%$ \\
\hline 2001 & 249,822 & 124,706 & $49.9 \%$ \\
\hline 2011 & 309,962 & 150,545 & $48.6 \%$ \\
\hline
\end{tabular}

Source: Department of Economic Planning and Development (Prime Minister Office, 2015)

The above figures justify that for the past thirty years Muslim women's population growth is consistent and stable with the growth of the opposite gender. According to Brunei Statistical Year Book 2015, women population in general for the previous four years (2012-2015) in which 2011 was the Census Year is in average growth of 48 percent from the whole population (Prime Minister Office, 2015). In such, the country has continuously given full attention and consideration to empower the education for women. This endless effort made by the government in helping women to upgrade their skills and professionalism can be seen in the Annual Report conducted by the Ministry of Education (formerly known as the Department of Education). Whereby, in the year of 1971 total students in Vernacular schools (Malay Schools) has increased but the rate of illiterate women in Brunei is relatively high which is about $41 \%$ compared to men, that their illiterate rate was only 21\%. In 1954 Annual Report stated that girls enrolling schools were only 713 pupils while boys were 2462 pupils in 36 schools during that time (Mail, 2006). In contrary, in these days a total of women that are literate has increased drastically and reached approximately $97.4 \%$. Although it did not specify its religions it was understood that Muslim women total percentage is the highest in this country. Thus a bigger percentage represents Muslim women in Negara Brunei Darussalam. It is also directly proved that the level of women's education is now moving to a higher level and apparently they are slowly dominating higher posts in government and private sectors.

These brief data on the achievement of women's education in Brunei will be highlighted in this paper to explore deeply on the history of empowerment of Muslim women's education. It also aims to demonstrate that the government is greatly concerned with the application of Wasatiyyah concept by giving the best and the fairest education regardless of the gender of the population.

\section{The Growth of Literacy Rate Among Women}

Even though schooling for women began relatively late as compared to men yet government as the leading agency was greatly concerned with improving the rate of literacy among women. The government took the initiatives to increase the literacy rate of women by teaching them to read and this effort was actually one of $W$ asatiyyah approaches. It has applied the concept of $W$ asatiyyah such as giving the best and being fair to all. Thus the tremendous efforts taken by the government was successful with the rate of literacy among women in this country reaching 50 percent. This rate was far beyond the target in 2015. Similarly, Brunei Darussalam has also provided equitable access to education from basic education to continuing education for an adult which is in line with the agreement in Dakar Framework 2000 (UNESCO, 2000).

This achievement has been reported in the Brunei Darussalam National Education for All 2015 (EFA) (Ministry of Education, 2015), which recorded the rate of adult literacy (15 years and above) that is people who can read and write with understanding a short simple statement 
to increase by 18.3 percent in the past 30 years (from $77.8 \%$ in 1981 to $87.8 \%$ in 1991). The literacy percentage increased rapidly to 92.7 percent in 2001 and has reached 96.1 percent in 2011 up to 97.4 percent in 2015. Meanwhile in the past ten years which is from 2001 to 2011 the rate of women youth literacy was above 99 percent (from $98.9 \%$ in 2001 and has increased to $99.3 \%$ in 2011).

This positive result shows government achievement in delivering various literacy programs for citizens especially women. The literacy programs in the country did not only target children but also to all ages including adult women. This boundless efforts made by various agencies cannot be considered as 'moderate' efforts rather as best efforts to ensure the best result for everyone. Therefore, literacy rate for youth in Brunei Darussalam as reported in EFA 2015 is among the highest in the region which reached above 99 percent. In this report, youth age group is defined from the age of 15 to 24 years old.

\section{Primary Education for Girls}

The education system in Brunei Darussalam has undergone various modifications in order to develop and improve. Its betterment process in the country has always been the interest of the highest authority. To ensure the nation's education is in line with the global demand, numerous initiatives have been carried out by the government.

Brunei Darussalam formal primary education has started its operation in 1930 with only 24 pupils (Padmore, 1958). This level of education was free for all. It was a government policy to give free education for all except for annual fees that only cost a few dollars (Brunei Annual Report, 1958). Government schools also provided textbooks at the beginning of the year for students to use during their study and return it back at the end of the year. Furthermore, all government primary schools in the country were provided with food and nutritious beverages and other necessities for free (Brunei Triennial Report 1955 -1957). The government had spent approximately Brunei Dollar amounting six hundred thousand per year to cater to more than four thousand students in forty schools across the country. This initiative was done together with the Department of Health (Brunei Annual Report, 1954). It was admitted that these benefits had opened the eyes of many parents and encouraged them to allow their children to enroll in school, particularly for their girls.

In 1954 the population of girl students had increased to 200 (Brunei Annual Report, 1954) and in 1957 the numbers hiked remarkably to 500 girls studied in Malay primary school for girls. The trend of girl students enrolling in Malay Girl School had made the school overpopulated and congested. Hence, in 1958 the old hostel built from wood was used as a temporary school so it could accommodate new students for the 1959 session. Apart from that, Malay primary schools had also developed rapidly and new schools were built in Kampung Ayer and also in Belait district (Padmore, 1958). The development was obviously notable with the statistic of girl student admission to schools constantly increasing each year. In 1960, the Annual Report stated that a total of 3,174 girl students enrolled in 49 Malay primary schools across the country. Although the numbers of boys still dominated, the gap between boys and girls at that time was getting closer. The population of boy student was 4,875 (Brunei Annual Report, 1960), whereas in 1958 boys were 49 percent higher compared to girls which reached 3,850 boys and 1,947 girls (Brunei Annual Report, 1958).

However, the biggest challenge during the time was many of the girls quitted from school after completing Year Four. To resolve this problem, in 1956 the government made another strategy besides providing food in school, they opted to grant selected students in Year Six with subsistence allowance in the total amount of Brunei Dollar three hundred and sixty dollars per year. This allowance was given as an incentive for students that willingly to continue their study up to Year Six. 
As the year passed by, parents' awareness on the importance of education for their girls has increased thus their enrolment to school has escalated. This awareness had been undeniably encouraged by the government's policy and fully support in disseminating the importance of education for all. In addition to this support, the government has anticipated the program to include education as the main agenda in the National Development Plan (Rancangan Kemajuan Negara-RKN) for 1954 - 1959. Then in 2007, the Compulsory Education Act was imposed that made children from the age of six and above and not yet attained the age of fifteen are compulsory to go to school. It is the parent or the guardian's obligation to ensure their children attend school.

In short, various initiatives carried out by the government demonstrate the seriousness of the country in upholding their duty and responsibility towards the nation. The government has provided a fair education for all without any disparity between genders. This explains that Wasatiyyah concept is duly practiced in this country as a platform to give the best to its people.

\section{Secondary Education for Girl}

Secondary education for girls has begun in 1954 with fifteen pupils in English Government School situated in Brunei Town. In 1957 the first-ever secondary school for girls was built. It was named Sekolah Tinggi Perempuan Raja Isteri (STPRI) or Raja Isteri High School for Girls and in 1959. It had 200 students learning there. The establishment of this school was one of the remarkable achievements for Brunei to produce educated future generation, especially for girls.

Even though according to the Annual Report on education in 1955-1957 showed that the girl's' population in all levels in schools were significantly low as compared to boys' population, but it was noticeably increasing every year. Then, after forty years later the statistic of girl enrolled in school has escalated drastically. This was during the early $90 \mathrm{~s}$ when the girls' statistic outnumbered boys' population in school. For instance, in 1992, the numbers of girl students were more than the boys in government lower and upper secondary schools. It was reported that the girl population in secondary schools were 11,134 whereas boys were only 10,060 (Ministry of Education, 1983-1992).

This positive progress in the girl enrolment in secondary schools was due to the country's policies that promote equity to both genders in having their free education. There is no restriction to obtain any level of education and the chances are justly given which certainly stated in the first National Development Plan (1953-1958): "Educating a boy means you are only educating one person, but if you educate a girl that denotes you are educating one whole family"

Thus, the concept of $W$ asatiyyah has been applied in governing the state. The absent of girl student in school during the early 50 s was not due to any restriction from the authority. This fact was mainly due to the myth where parent believed that all girls regardless her achievements in academic will end up working in the kitchen (an old Malay folk perception that indicates women will forever be a housekeeper taking care of their family and no suitable career for her outside to apply her skill and ability). Thus, this explains the reasons for girls in the era of 50's most of them were asked to marry early at their teenage age.

\section{Higher Education for Girl}

The research will only be focusing on a tertiary level that is two Islamic higher institutions, namely Universiti Islam Sultan Sharif Ali (UNISSA) and Kolej Perguruan Ugama Seri Begawan (KUPU SB). These institutions are chosen in this study because the students studying in both institutions are all Muslims. As for the secondary and primary level, the research will only focus on public schools since the majority of the students are Muslim. Therefore, statistics mentioned in this paper were all referred to public schools that run by the government. 
In 2007, the first Islamic higher education institution was established by the commandment of His Majesty Sultan dan Yang Di-Pertuan. The institution was the second national university in the reign of His Majesty. The formation of Universiti Islam Sultan Sharif Ali (UNISSA) indicates the advancement of education in Brunei and another milestone for the higher institution, especially in Islamic Studies. Likewise, in the primary and secondary level, there is no gender constraint. Currently, female enrolment and graduates were much higher than male. This has been clearly shown in Brunei Statistical Yearbook 2013 \& 2015 for the admission and graduates statistic in UNISSA and KUPU SB, which from the first convocation (Hafl alTakbarruj) in 2011 until 2015 there were 367 female graduates, whereas male graduates were only 253. Similarly, in KUPU SB, the same phenomenon occurred, from 2011 until 2015, there were 716 female graduates and only 384 male graduates. Both institutions commenced their first enrolment in 2007.

This manifestation proved that State Education Policy practices are fair, equitable and excellent to serve the best for all. In other words, the application of Wasatiyyah concept in education specifically for women has shown it the success that gives benefit to women and the nation as a whole. It also follows the Rabbanni concept in being just to equip women with knowledge and become expert in their own field of specialization. Thus, in classical Islamic books reported by Muslim scholars have recorded that numbers of women companions (sahabiyat) went to the Prophet (peace be upon him) to seek knowledge. They became intellectuals and scholarly recognized by the public and became narrators in the prophetic traditions which their narrations were recorded in the canonical books of hadith.

\section{Adult Education Classes for Female}

The authority started the adult education classes nationwide in 1955 which had two centers, which one of them situated in Brunei Town (Sultan Omar Ali Saifuddien CollegeSOASC) and the other center was situated in Seria (Government English School). In 1958, according to the report, there were more than 1,161 students adults attending classes (Padmore, 1958). The objective of introducing classes for adults was as stated in the Annual Education Report: ("...offering opportunity for those who are not capable of reading and writing to all male and female adults to acquire skill and proficiency needed") (Ministry of Education, 1984). In 1971, the government showed their commitments in eradicating illiteracy amongst adults by opening twenty-two centers for adult education classes in the country including remote area (Department of Education, 1971). This opportunity aimed to improve their knowledge and enhance their skill regardless of their age.

This is exactly in line with Wasatiyyah concept to produce the excellent ummah (khayr ummah) and continue on pursuing knowledge at all time. The Prophet (peace be upon him) himself was determined to improve and refine his ability in reading Qur'an until the year he died when he managed to complete his reading twice with Jibril 'alaibissalam. The purpose of reading the Qur'an was nothing but to study the accurate way to recite the Qur'an.

Then in 1966 Annual Education Report presented that there were 2,935 female students studying in various courses conducted in Malay and English languages that have been offered by the state (Education Department, 1966). The government continuously encourages lifelong learning to accommodate current needs, therefore adult education classes that were operated under the Department of Education being transferred to the Department of Technical Education in 1993. With the new strategy, the prime objective is not mainly in eradicating illiteracy amongst adult rather than broaden the scope of studies to other areas or fields to encourage lifelong learning.

In this regard, higher institutions have taken their proactive step by opening centers for lifelong learning by offering various periodical programs. As such, UNISSA has established Centre for Leadership and Lifelong Learning that offers numerous programs for the public. 
Among the programs are Tadabbur al-Qur'an (Reflection of Qur'an) and there are also special classes operated upon request by a group of women. Hence, UNISSA has provided them, special classes, to ease them in their learning. The classes are conducted during weekends and taught by UNISSA's lecturers.

Apart from the Ministry of Education, courses for continuing education or classes for lifelong learning are currently conducted by the Ministry of Religious Affair. It was officially started its operation in 1963. The objective was to instill religious awareness in every adult that has missed their chances to learn Islamic studies (Ministry of Religious Affair, 2009). There are many Quranic classes that have been offered to increase the rate of Qur'anic literacy, as well as classes for Fardhu 'Ain specifically conducted for Muslim women organized by mosques. In addition, some mosques have formed a Muslim Women committee that would be responsible to organize religious activities to enhance their understanding in performing ibadah. This committee can be seen actively handling different type of courses related to women in their respective mosques. The activities are getting highly supported by the Department of Mosques Affair which they also set up Muslimah Affair division to monitor and plan any related activities organized by the Muslim Women committee in their mosques. With these activities, the opportunities all Muslim women in the state are widely encouraged to seek and improve their religious knowledge. Moreover, most of the classes conducted are free of charge and only a few courses offered with minimum charges. These classes that specifically organized for Muslim women are a valuable opportunity offered by the government to enhance women's education in accordance with promoting no disparity between genders (UNESCO, 2000). This also means there shall be no restrictions or specific allocation for women in education in this country. Thus, this clearly has shown that the application of Wasatiyyah concept has been implemented for a while in promoting the excellent and best education for adult women in Brunei.

\section{Religious Arabic School for Girls}

The religious Arabic school for girls has officially begun its operation and enrolment in 1967. The placement of the foundation-stone was laid by His Majesty Al-Marbum Sultan Haji Omar 'Ali Saifuddien Sa'adul Khairi Waddien in June 1966. This religious school was known as Raja Isteri Pengiran Anak Damit Secondary Arabic Religious School for Girls/Sekolah Ugama Arab Menengah Perempuan Raja Isteri Pengiran Anak Damit (SUAMPRIPAD) and today it has been operating for more than fifty years.

An interesting fact is that the religious school for girls in Brunei Darussalam was introduced when the country's population was still in a small-scale. Clearly, this was the highest authority's initial involvement in a religious affair for a female to show their great support in strengthening Muslim's women belief in Islam. It can be seen precisely in the decree delivered by His Majesty al-Marhum Sultan Haji Omar 'Ali Saifuddien Sa'adul Khairi Waddien during officiating the placement-stone of SUAMPRIPAD, he has mentioned that the aimed for establishing SUAMPRIPAD was to produce hundreds or thousands female scholars that are knowledgeable in religious affair and development matter for the benefit of the country. (Dewan Bahasa dan Pustaka, 1971).

The development of religious education amongst the people in Brunei cannot be denied since Islam is the official religion as stated in the Constitution of Brunei 1959. It was also mentioned that the practice shall be aligned with Abli Sunnab wa al-Jama'ah. Furthermore, in order to portray the urgency of the authority in embracing Islam and its practice as the official religion, The Compulsory Religious Education Order 2012 came into force at the beginning of 2013.

Nowadays, Religious Arabic School for the girl has progressed significantly when the new building was officially used in early 2017 and known as Raja Isteri Pengiran Anak Saleha Secondary Religious Arabic School/Sekolah Ugama Arab Menengah Perempuan Raja Isteri Pengiran 
Anak Saleha (SUAMPRIPAHS). This new building is situated in Kampong Katok, Bandar Seri Begawan. Currently, there are more than 1,300 students studying from Year 7 until Year 11. The school's management, administration and particularly the curriculum of government nationwide are being monitored under the Department of Islamic Studies. In ensuring the curriculum especially in Arabic subjects are up to date, the benchmark was set to the curriculum in Ma'had Bubuth al-Islamiah (College of Islamic Research), Cairo. This College is equivalent to secondary level and is acknowledged by al-Azhar University.

All great efforts in preparing Muslim women to be intellectually fit for their future and be able to contribute to the religious development of a nation is relevant with the decree announced during the formation in 1966. Application of $W$ asatiyyah concept can be observed particularly in fair chances given for both male and female gender to attain knowledge and furthering their study to a higher level.

\section{CONCLUSION}

During World Economic Forum regarding Global Gender Gap, it was reported that Brunei Darussalam was ranked in $7^{\text {th }}$ place in the registration and admission for a female to a higher institution. This positive statement was undoubtedly resulted came from the government's perseverance that believed in the importance of education. Education is undeniably one of the nation's important agenda as a mechanism to produce intellectuals as an essential asset to the country and future development. Therefore, it was an appropriate strategy in emphasizing the agenda of educating and empowering women's ability as the major agenda since women are contributing to the development of the country. The contribution to the country basically begins with giving them trust thus it will accelerate their productivity and contribute to the growth of the economy through various sectors and ways.

It was inevitable to conclude that the $W$ asatiyyah concept has been applied in women's education which was visibly implemented in all levels of education. Besides, Muslim women also have similar chances as a male in education and are encouraged to pursue their study to the highest level. Apart from that, government schools provided students with food and transportation as well as subsistence allowance. Furthermore, both male and female students are given scholarship abroad if they are qualified to further their study overseas. It is significant to mention that in time of economic crisis the government also continued to provide a scholarship to the best achievers despite their disparity of genders. This evidenced has proven that the state is very much committed to practicing the best and the fairest education systems as promote by Wasatiyyah concept.

Empowering Muslim women's education is crucial in achieving Brunei's Vision 2035 (Wawasan Negara 2035). This empowerment is expected to produce educated people, highly skilled and successful measure by international standards. Hence, the characteristic in $W$ asatiyyah concept has to be highlighted and continuously practice. However, in the meantime, one should not define Wasatiyyah as purely "moderation". The term should address the meanings: the best and the fairest as well as justly balanced. One cannot merely claim that $W$ asatiyyah is the opposite of extremism while using moderation to interpret the concept of Wasatiyyah.

\section{BIBLIOGRAPHY}

Afsaruddin, A. (2009). The hermeneutics of inter-faith relations: retrieving moderation and pluralism as universal principles in Qur'anic exegeses. The Journal of Religious Ethics, 37(2). Retrieved from https://www.jstor.org/stable/40378048

Al-Razi, M. bin 'U. (1420H). Mafatih al-Ghayb. Beirut: Dar Ihya al-Turath al-'Arabiy.

Al-Tabari, A. J. M. bin J. (2000). Jami'al-Bayan fi Ta'wil al-Qur'an.

Al-Tirmizi, M. I (1998). Sunan al-Tirmizi. Beirut Dar al-Garb. 
Al-Qurtubi, M. A (1964). al-Jami' li Ahkam al-Qur'an. Cairo: Dar al-Kutub al-Masriyyah.

Brunei Annual Report. (1954).

Brunei Annual Report. (1958).

Brunei Annual Report. (1960).

Department of Economic Planning and Development. Prime Minister Office. (n.d.). Brunei Statistical Yearbook 2015.

Department of Education. (1971). Annual Report 1971 (p. 17).

Dewan Bahasa dan Pustaka. (1971). Titah KDYMM Paduka Seri Baginda Maulana al-Sultan Sir Omar Ali Saifuddin Sa'dul Khairi Waddin 1959-1967. Brunei: Dewan Bahasa dan Pustaka.

Edcridge, D. (1995). Research Methodology in Applied Economics. University Press.

Education Department. (1966). Brunei Education Triennial Report 1964-1966 (p. 61).

Fox, W., \& Bayat, M. S. (2008). A guide to managing research. Juta and Company Ltd.

Islam, F., Rahman, A., Khatoon, N., Kumar Pathak, V., \& Ali Imam, M. (2014). Comparative Study of Muslim Women's Education in the Context of employment, access to media, marital status, family planning and political participation - Case Study of Azamgarh District. IOSR Journal of Humanities and Social Science, 19, 186-196. https://doi.org/10.9790/0837-1932186196

Juned, A. A. (2015). Wasatiyyah Asas Kesejahteraan Sejagat. Secretariat of Seminar Majlis Ilmu 2015.

Khotari, C. R. (2004). Reserch methodology: method and techniques (second revised edition). New Delhi: New Age International.

Mail, A. bin H. (2006). Persekolahan Melayu di Brunei Darussalam 1950-1984: Perubahan dan Cabaran.

Mcclendon, D., Hackett, C., Potančoková, M., Stonawski, M., \& Skirbekk, V. (2018). Women’s Education in the Muslim World. Population and Development Review. https://doi.org/10.1111/padr.12142

Miles, M. B., Huberman, A. M., Huberman, M. A., \& Huberman, P. M. (1994). Qualitative data analysis: An expanded sourcebook. SAGE Publications. Retrieved from https://books.google.co.id/books?id=U4lU_-wJ5QEC

Ministry of Education. (1984). Education Annual Report 1981-1984 (p. 78).

Ministry of Education. (2015). Brunei Darussalam National Education for All 2015 Report.

Ministry of Education. (n.d.). Education Statistic 1983-1992.

Ministry of Religious Affair. (2009). 50 Tabun dalam Ristaan Perkbidmatan Hal Ehwal Ugama Negara Brunei Darussalam (1959-2009).

Mohd Zain, N. (2014). Justly Balanced (Wasatiyyah): A Cure for Laxity or Extremism in Appreciation of Legal Rules in Islam, 75-100.

Padmore, H. J. (1958). Brunei Education Triennial Report 1955-1957.

Pelita Brunei. (2016). Retrieved from http://www.pelitabrunei.gov.bn /Arkib\%20Dokumen/2016/Febuari/pelitabrunei_200216.pdf.

Rahmawati, A. (1998). Al-Imam Al Tirmidzi: Perannya dalam pengembangan hadis dan fiqih. Logos Wacana Ilmu.

UNESCO. (2000). The Dakar Framework for Action. 